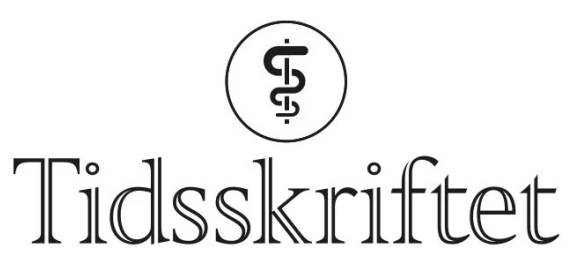

DEN NORSKE LEGEFORENING

\title{
Alzheimers sykdom - diagnostikk og behandling
}

\author{
KLINISK OVERSIKT
}

\section{ANNE-BRITA KNAPSKOG}

anne-brita@knapskog.net

Hukommelsesklinikken

Geriatrisk avdeling

Oslo universitetssykehus

Hun har bidratt med utforming, første utkast og innspill til litteratur, innhold og revisjon av manuset.

Anne-Brita Knapskog er overlege og leder av demensforskningsgruppen ved Hukommelsesklinikken. Forfatteren har fylt ut ICMJE-skjemaet og oppgir følgende interessekonflikter: Hun har tidligere vært ansvarlig for utprøvingen av legemiddelstudier i regi av Roche og Boehringer Ingelheim.

\section{KNUT ENGEDAL}

Nasjonal kompetansetjeneste for aldring og helse

Sykehuset i Vestfold

og

Geriatrisk avdeling

Oslo universitetssykehus

Han har bidratt med innspill til litteratur, innhold og revisjon av manuset.

Knut Engedal er alderspsykiater, professor emeritus og seniorforsker.

Forfatter har fylt ut ICMJE-skjemaet og oppgir ingen interessekonflikter.

\section{GEIR SELBAK}

Nasjonal kompetansetjeneste for aldring og helse Sykehuset i Vestfold

og

Geriatrisk avdeling

Oslo universitetssykehus

Han har bidratt med innspill til litteratur, innhold og revisjon av manuset.

Geir Selbæk er alderspsykiater, professor og forskningsleder.

Forfatteren har fylt ut ICMJE-skjemaet og oppgir følgende interessekonflikter: Han sitter i Biogens rådgivende utvalg.

\section{ANNE-RITA ØKSENG ÅD}

Nasjonalforeningen for folkehelsen

Hun har bidratt med idé til manus og innspill til litteratur, innhold og revisjon.

Anne-Rita $\emptyset$ ksengård er geriater og forskningsleder.

Forfatter har fylt ut ICMJE-skjemaet og oppgir ingen interessekonflikter. 


\section{Alzheimers sykdom er den hyppigste årsaken til demens i verden. Forekomsten vil øke betydelig i årene som kommer, i takt med at andelen eldre øker. Det er foreløpig ingen sykdomsmodifiserende behandling tilgjengelig. Risikoforebyggende tiltak midt i livet kan potensielt forhindre eller utsette opptil $40 \%$ av demenstilfellene på gruppenivå.}

Demens er et syndrom forårsaket av sykdommer som fører til kognitiv svikt, endret atferd og sviktende egenomsorg. Alder er den sterkeste risikofaktoren for demens. De eldste har ofte multifaktorielle årsaker til demens grunnet komorbiditet. Blant yngre er blandingspatologi mindre vanlig. Om lag 2-5\% av de som utvikler demens får tilstanden før fylte 65 år (1). Hos omtrent $40 \%$ av tilfellene er risikoen $ø$ kt grunnet potensielt modifiserbare forhold som lav utdannelse, hypertensjon, overvekt, redusert hørsel, depresjon, diabetes, redusert fysisk aktivitet, røyking og sosial isolasjon (2).

Ved Alzheimers sykdom (Alzheimer's disease, AD) skjer det en gradvis utvikling av symptomer knyttet til tap av kortikale funksjoner. Klinisk er det to fenotyper av sykdommen, amnestisk og ikke-amnestisk form (3). Ved amnestisk form debuterer sykdommen med redusert hukommelse for nylige hendelser eller samtaler (episodisk hukommelse) og problemer med tidsorientering. Symptomer som redusert forståelse, vurderingsevne, tankevirksomhet og språkvansker utvikler seg etter hvert. Ved den ikkeamnestiske formen debuter sykdommen med atferdsendring, depresjon, språkvansker, orienteringsvansker eller visuelle problemer.

Alle utvikler med tiden global kognitiv svikt, ulike atferds- og psykologiske symptomer samt funksjonssvikt, og de fleste får motoriske symptomer og autonom dysfunksjon. De har en betydelig redusert forventet livsutsikt sammenlignet med sine jevnaldrende (4).

De fleste tilfellene av Alzheimers sykdom er sporadiske, dvs. uten kjent familiær belastning (5). Genotypen APOE- $\varepsilon 4$ er det hyppigst forekommende risikoallelet for utvikling av sykdommen og forekommer hos omlag $15 \%$ i Norden ( $\underline{6}$ ). Tidlig debuterende familiær Alzheimers sykdom med mutasjoner i amyloid forløperprotein (amyloid precursor protein, APP), presenilin-1 (PSEN1) eller presenilin-2 (PSEN2) er sjeldent. I tillegg er $>50$ gener eller genloci assosiert med sykdommen, men med lav penetrans $(7, \underline{8})$.

\section{Klinisk versus biologisk definisjon av Alzheimers sykdom}

Klinisk stilles diagnosen Alzheimers sykdom basert på det klassiske symptombildet og progresjonen. Klinisk utvikler sykdommen seg fra subjektive symptomer via mild kognitiv svikt til en etablert klinisk demenssykdom. Utviklingen av nye diagnostiske biomarkører har gitt økt biologisk forståelse av sykdommen, men dette har samtidig synliggjort at det ofte foreligger blandingspatologi. En finner også en betydelig biomarkørvariasjon hos pasienter med samme symptombilde (모). Forskning for å utvikle nye diagnostiske biomarkører har vært intens de siste tiårene innenfor områder som genetikk, epigenetikk, blod, cerebrospinalvæske og urin. I tillegg forskes det på avansert strukturell og funksjonell bildediagnostikk.

I denne artikkelen gir vi en oversikt over anbefalt prosedyre i demensutredningen, tilgjengelige og mulige fremtidige biologiske diagnostiske markører og nåværende og potensielle farmakologiske behandlingsmetoder for Alzheimers sykdom. Artikkelens kunnskapsgrunnlag baserer seg på relevant forskningslitteratur og forfatternes kliniske erfaring.

\section{Basal og utvidet demensutredning}


De fleste personer med kognitive symptomer skal utredes i kommunehelsetjenesten (9.). Den basale demensutredningen begynner hos fastlegen eller sykehjemslegen, ofte i samarbeid med et tverrfaglig team som de fleste norske kommuner har etablert. I spesielle tilfeller bør utredningen skje i spesialisthelsetjenesten. Dette gjelder yngre personer, personer med annen kulturell bakgrunn eller utviklingshemming samt ved vanskelige og atypiske symptomer. Henvisning til både nevrologiske, geriatriske og alderspsykiatriske avdelinger kan være aktuelt. En demensdiagnose baserer seg på en kombinasjon av anamnestiske opplysninger (også fra komparent), symptompresentasjon, kognitiv testing, somatisk unders $\varnothing$ kelse og strukturelle og funksjonelle undersøkelser av hjernen. For mer informasjon henviser vi leserne til den nasjonale faglige retningslinjen for demens (9.). Utredningsverktøy og veiledninger til bruk både i basal og utvidet utredning er fritt tilgjengelig på Aldring og helse sin hjemmeside (10).

\section{Patofysiologiske og nevrokjemiske forandringer}

De patologiske endringene i hjernen begynner sannsynligvis 10-20 år før symptomdebut, og utviklingen av nye biomarkører muliggjør påvisning av AD-forandringer på et asymptomatisk stadium (11). Sykdommen starter med dannelse og avleiring av uløselige amyloide plakk ekstracellulært. Intracellulært skjer en fosforylering av tau-proteiner som resulterer i at det dannes nevrofibrillære floker. Nevronene skades, immunsystemet aktiveres, og det oppstår vaskulære forandringer. Reseptorene på nervesynapsene skades, og produksjonen av flere nevrotransmittersubstanser reduseres ( $\underline{8}$ ) (figur 1 ).

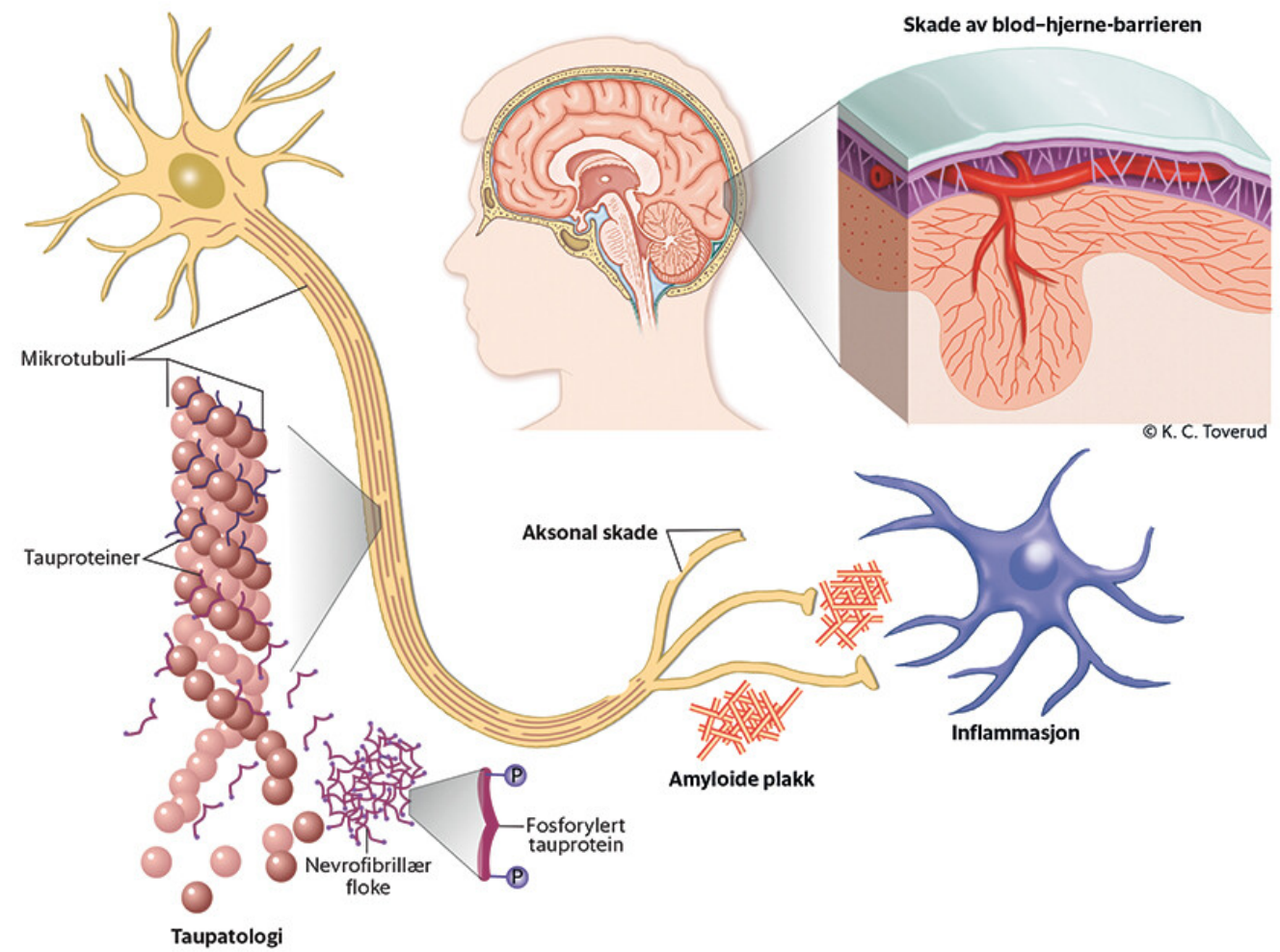

Figur 1 Skjematisk fremstilling av de vanligste nevropatologiske forandringene ved Alzheimers sykdom, med ekstracellulær avleiring av amyloide plakk, intracellulær fosforylering av tau-proteiner, nevronskade, immunaktivering og vaskulære forandringer med skadet blod-hjerne-barriere.

\section{Spinalvæskeundersøkelser}

Nivåene av løselig amyloid, fosforylert tau og total-tau kan måles i spinalvæsken og brukes diagnostisk. Det er en invers sammenheng mellom spinalvæske-amyloid og amlyoide plakk i hjernen. Nivåene av løselig amyloid er lavere hos personer med Alzheimers sykdom 
og APOE- $\varepsilon 4$ positive personer, men reduseres også noe med $\emptyset$ kende alder $(\underline{12})$. Personer med lewylegemedemens, vaskulær demens og frontotemporal demens kan også ha noe lavere verdier av amyloid (13). Total-tau er en uspesifikk markør på nevronskade og stiger ved mange tilstander. Fosforylert tau anses derimot som AD-spesifikt (11, 14). Ved tolkning av demensmarkørsvarene bør en ikke vektlegge enkeltresultatene, men se dem i sammenheng. Minst to av tre markører bør være patologiske når en setter diagnosen Alzheimers sykdom (11, 14.).

Demensmarkørene kan brukes som et diagnostisk hjelpemiddel, men ikke for klinisk stadieinndeling eller som prognostisk mål.

\section{Bildeundersøkelser}

Hjerneforandringene starter hos de fleste i entorhinal korteks. På magnetresonanstomografi (MR) av hjernen (eventuelt computertomografi (CT) ved kontraindikasjon mot MR-undersøkelse) kan det i klassiske tilfeller ses atrofi av hippocampus i mediale temorallapper, gradert fra o (ingen atrofi) til 4 (uttalt atrofi) (15).

Positronemisjonstomografi med fluor-18-merket deoksyglukose (FDG PET) som måler metabolsk aktivitet i hjernen kan brukes, spesielt når MR-funnene er mindre uttalt og en er usikker på diagnosen. Ved Alzheimers sykdom ser en i typiske tilfeller redusert metabolisme temporoparietalt.

Amyloid-PET med flutemetamol kan vurderes når spinalpunksjon ikke er tilrådelig. Denne undersøkelsen påviser amyloidavleiringer i korteks. Det er viktig å være klar over at amyloidavleiring er vanlig med økende alder, og resultatet må derfor ses i sammenheng med klinikk og pasientens alder.

\section{Genotyping}

Genotypen APOE- $\varepsilon_{4}\left(\varepsilon_{2} / \varepsilon_{4}, \varepsilon_{3} / \varepsilon_{4}\right.$ eller $\left.\varepsilon_{4} / \varepsilon_{4}\right)$ har en redusert penetrans, slik at denne markøren ikke kan brukes på individnivå. Genotyping anbefales derfor ikke brukt i klinisk praksis. På gruppenivå vil > 50 \% av homozygote bærere utvikle Alzheimers sykdom (7.). Av mutasjonene PSEN1, PSEN2 og APP, er PSEN1 den hyppigste med antatt full penetrans for sykdommen. Genanalyse er tilgjengelig og kan vurderes i tilfeller med familiær demensopphopning.

\section{Andre undersøkelser}

Ulike ${ }^{18}$ F-ligander er utviklet for å påvise AD-relatert tau-patologi, men tau-PET er foreløpig ikke tilgjengelig i Norge. I forskning er tau-PET funnet mer spesifikk for Alzheimers sykdom enn både CSF-markører og amyloid-PET (16). Det forskes også på andre markører i cerebrospinalvæsken (17.). Blodbaserte diagnostiske tester ville øke tilgjengeligheten og redusere kostnader. Foreløpig fins ingen blodbaserte markører med god validitet, men

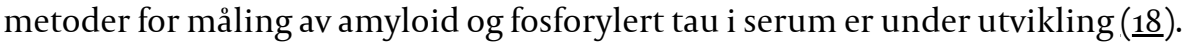

\section{Symptomatisk behandling}

Dagens tilgjengelige medikamentelle behandling i den vestlige verden er symptomlindrende med individuell, moderat og tidsavgrenset effekt. To ulike legemiddelgrupper er tilgjengelige i Norge, kolinesterasehemmere og den ikkekompetitive N-metyl-D-aspartat (NMDA)-reseptorantagonisten memantin. Den nasjonale faglige retningslinjen om demens anbefaler å gjøre et behandlingsforsøk hos alle med mild til moderat grad av AD-demens med en kolinesterasehemmer (9.). Memantin anbefales kun 
når kolinesterasehemmere ikke tolereres eller ikke har effekt ved langtkommen ADdemens. Kombinasjon av de to legemidlene er kun unntaksvis anbefalt i retningslinjen (9.). De tre kolinesterasehemmerne rivastigmin, donepezil og galantamin anses å ha lik klinisk effekt, men noe ulik bivirkningsprofil. De har ingen dokumentert effekt på mild kognitiv svikt og forsinker heller ikke utviklingen av demens (19.). Effekten ved langtkommen

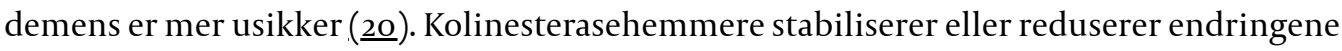

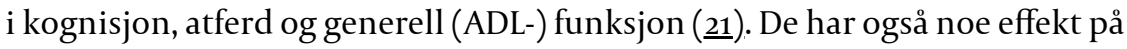
synshallusinasjoner, spesielt hos personer med demens ved lewylegemer. I et forsøk på å redusere bruken av psykofarmaka hos personer med demens, viser tall fra det svenske demensregisteret (Swedem) at kolinesterasehemmere i $ø$ kende grad blir benyttet mot atferds- og psykologiske symptomer (22). Det foreligger derimot ingen god dokumentasjon på effekt.

De vanligste bivirkningene er gastrointestinale (diare, kvalme og oppkast), men svimmelhet, hodepine og søvnvansker inkludert mareritt er også hyppig forekommende. Da kolinesterasehemmere kan gi bradykardi, må en være forsiktig hos personer med kardiale ledningsforstyrrelser eller ved bruk av andre legemidler som påvirker hjertes ledningsevne (f.eks. betablokkere).

Memantin hemmer glutamats effekt ved å virke antagonistisk på NMDA-reseptoren. Indikasjonen er moderat til alvorlig AD-demens.

\section{Sykdomsmodifiserende behandling}

Utviklingen av nye legemidler kan deles inn i sykdomsmodifiserende legemidler og symptomatisk behandling av kognisjonsforbedrende art og atferds- og psykologiske symptomer (23).

Utviklingen av nye sykdomsmodifiserende legemidler har vært rettet mot endring av amyloid eller tau-patologi. I tillegg gjøres det i økende grad utprøvinger av legemidler rettet mot metabolisme, inflammasjon, synapse eller nevronal beskyttelse, samt vaskulære og epigenetiske intervensjoner (23). Majoriteten av utprøvingene har vært rettet mot å forhindre dannelse av amyloide plakk ( $\beta$-sekretase-inhibitorer), motvirke aggregasjon eller $\emptyset$ ke nedbrytningen av amyloid (antiamyloid immunterapi), og forhindre fosforylering av tau (antitau immunterapi). Mest oppmerksomhet har det vært på utprøving av nye aktive og passive immunterapier mot amyloid, hvor utprøvingene har pågått lengst. For tiden er det fem legemidler under utprøving i fase tre, men ingen har hittil kunnet dokumentere sikker klinisk effekt. Biogens preparat aducanumab har kommet lengst i prosessen og er for tiden til vurdering hos The US Food and Drug Adminstration (FDA). Endelig avgjørelse om godkjenning ventes i juni 2021.

Utvikling av nye medikamenter mot Alzheimers sykdom er etterspurt av både pasienter og pårørende. Den lange prekliniske fasen av Alzheimers sykdom gjør det derimot etisk krevende å utvikle nye medikamenter. Sykdomsmodifiserende legemidler må igangsettes på et tidspunkt uten eller med få symptomer på bakgrunn av biomarkørpåviste forandringer, muligens mange år før de ville fått symptomer.

\section{Forebyggende tiltak}

Foreløpig er det kun forebyggende tiltak en antar har effekt på reduksjon av prevalens på gruppenivå. En rekke helsefremmende tiltak er foreslått for å redusere risikoen for demens $(\underline{2}, 24)$. På linje med å redusere den individuelle risikoen for hjerte- og karsykdom, vektlegges den mulige effekten av fysisk aktivitet, forebygge hodetraumer, røykestopp, sunt kosthold, moderat alkoholinntak, vekt og blodtrykkskontroll, god regulering av diabetes mellitus samt hjelpemidler ved hørselstap. I tillegg vet vi at utdanning $ø$ ker den kognitive reserven og dermed beskytter mot kognitiv svikt (19).). 
1. Kvello-Alme M, Bråthen G, White LR et al. The prevalence and subtypes of young onset dementia in central Norway: A population-based study. J Alzheimers Dis 2019; 69: 479-87. [PubMed][CrossRef]

2. Livingston G, Huntley J, Sommerlad A et al. Dementia prevention, intervention, and care: 2020 report of the Lancet Commission. Lancet 2020; 396: 413-46. [PubMed][CrossRef]

3. McKhann GM, Knopman DS, Chertkow $\mathrm{H}$ et al. The diagnosis of dementia due to Alzheimer's disease: recommendations from the National Institute on Aging-Alzheimer's Association workgroups on diagnostic guidelines for Alzheimer's disease. Alzheimers Dement 2011; 7: 263-9. [PubMed] [CrossRef]

4. Strand BH, Knapskog AB, Persson Ket al. Survival and years of life lost in various aetiologies of dementia, mild cognitive impairment (MCI) and subjective cognitive decline (SCD) in Norway. PLoS One 2018; 13: e0204436. [PubMed][CrossRef]

5. Bertram L, McQueen MB, Mullin Ket al. Systematic meta-analyses of Alzheimer disease genetic association studies: the AlzGene database. Nat Genet 2007; 39: 17-23. [PubMed][CrossRef]

6. Kern S, Mehlig K, Kern J et al. The distribution of apolipoprotein E genotype over the adult lifespan and in relation to country of birth. Am J Epidemiol 2015; 181: 214-7. [PubMed][CrossRef]

7. Scheltens P, Blennow K, Breteler MM et al. Alzheimer's disease. Lancet 2016;388: 505-17. [PubMed] [CrossRef]

8. Lukiw WJ, Vergallo A, Lista S et al. Biomarkers for Alzheimer's Disease (AD) and the application of precision medicine. J Pers Med 2020; 10: 138. [PubMed][CrossRef]

9. Helsedirektoratet. Nasjonal faglig retningslinje om demens.

https://www.helsedirektoratet.no/retningslinjer/demens Lest 21.1.2021.

10. Nasjonal kompetansetjeneste for aldring og helse. https://www.aldringoghelse.no/demens/ Lest 21.1.2021.

11. Jack CR, Bennett DA, Blennow K et al. NIA-AA Research Framework: Toward a biological definition of Alzheimer's disease. Alzheimers Dement 2018; 14: 535-62. [PubMed][CrossRef]

12. Jansen WJ, Ossenkoppele R, Knol DL et al. Prevalence of cerebral amyloid pathology in persons without dementia: a meta-analysis. JAMA 2015; 313: 1924-38. [PubMed][CrossRef]

13. Schoonenboom NS, Reesink FE, Verwey NA et al. Cerebrospinal fluid markers for differential dementia diagnosis in a large memory clinic cohort. Neurology 2012; 78: 47-54. [PubMed][CrossRef]

14. Blennow K, Dubois B, Fagan AM et al. Clinical utility of cerebrospinal fluid biomarkers in the diagnosis of early Alzheimer's disease. Alzheimers Dement 2015; 11: 58-69. [PubMed][CrossRef]

15. Scheltens P, Leys D, Barkhof F et al. Atrophy of medial temporal lobes on MRI in "probable" Alzheimer's disease and normal ageing: diagnostic value and neuropsychological correlates. J Neurol Neurosurg Psychiatry 1992; 55: 967-72. [PubMed][CrossRef]

16. Ossenkoppele R, Rabinovici GD, Smith R et al. Discriminative Accuracy of [18F]flortaucipir Positron Emission Tomography for Alzheimer Disease vs Other Neurodegenerative Disorders. JAMA 2018; 320: 1151-62. [PubMed][CrossRef]

17. Palmqvist S, Insel PS, Stomrud E et al. Cerebrospinal fluid and plasma biomarker trajectories with increasing amyloid deposition in Alzheimer's disease. EMBO Mol Med 2019; 11: e1117o. [PubMed] [CrossRef]

18. Cullen NC, Leuzy A, Palmqvist S et al. Plasma amyloid, phosphorylated tau, and neurofilament light for individualized risk prediction in mild cognitive impairment. medRxiv. Preprint 24.7.2020. https://www.medrxiv.org/content/10.1101/2020.07.21.20159129v1 Lest 21.1.2021.

19. Livingston G, Sommerlad A, Orgeta V et al. Dementia prevention, intervention, and care. Lancet 2017;390: 2673-734. [PubMed][CrossRef]

20. Birks J. Cholinesterase inhibitors for Alzheimer's disease. Cochrane Database Syst Rev 2006; nr. 1: CDoo5593. [PubMed]

21. Tan CC, Yu JT, Wang HF et al. Efficacy and safety of donepezil, galantamine, rivastigmine, and memantine for the treatment of Alzheimer's disease: a systematic review and meta-analysis. J Alzheimers Dis 2014; 41: 615-31. [PubMed][CrossRef]

22. Tan ECK, Johnell K, Bell JS et al. Do acetylcholinesterase inhibitors prevent or delay psychotropic prescribing in people with dementia? Analyses of the Swedish Dementia Registry. Am J Geriatr Psychiatry 2020; 28: 108-17. [PubMed][CrossRef] 
23. Cummings J, Lee G, Ritter A et al. Alzheimer's disease drug development pipeline: 2020. Alzheimers Dement (N Y) 2020; 6: e12050. [PubMed][CrossRef]

24. Risk Reduction of Cognitive Decline and Dementia: WHO Guidelines. Geneve: World Health Organization, 2019.

https://www.who.int/mental_health/neurology/dementia/guidelines_risk_reduction/en/Lest 21.1.2021.

Publisert: 29. april 2021. Tidsskr Nor Legeforen. DOI: 10.4045/tidsskr.20.0919

Mottatt 11.11.2020, første revisjon innsendt 21.1.2021, godkjent 4.3.2021.

Publisert under åpen tilgang CC BY-ND. Lastet ned fra tidsskriftet.no 26. april 2023. 